\section{フラクタル次元解析を用いた景 観認知による可視化モデルの複 雑性の定量化手法}

QUANTIFICATION TECHNIQUE OF COMPLEXITY IN VISUALZATION MODELS BY THE LANDSCAPE RECOGNITION USING THE FRACTAL DIMENSION ANALYSIS

\section{蝶名林秀明 $-* 1 \quad$ 根來宏典 — \\ 大内宏友 - $* 3$ \\ キーワード \\ フラクタル, 景観認知, 可視化モデル, 3 次元陰影画像, 複雑性, 沿岸漁村地 域}

Keywords :

Fractal, Landscape recognition, Visualzation model 3D-shade image, Complexity, Coastal fishing villages

\section{Hideaki CHONABAYASHI $-* 1$ Hirotomo OHUCH $-* 3$}

\section{Hironori NEGORO — $* 2$}

This study show it for an index to be quantitative by using fractal dimension analysis about the complexity of visualzation models by the landscape recognition with 3D-shade images based on a viewpoint of local inhabitants in coastal fishing villages.

As a summary of fractal dimension analysis with box-counting method, it is thought that a unity of villages classified by a continuity mode of a fractal dimension in a process making box size big, has similar structure.

\section{1. はじめに}

近年、科学の専門領域間をつなぐ複合領域や学際的・横断的テー マに関する研究成果があがるにつれ、フラクタル、非線形、自己組 織化、カオスといった複雑系科学の重要性が社会的な脚光を浴びて いる。本稿で取り扱うフラクタルは、部分と全体が相似であるとい う自己相似性であり、自然界に潜在する複雑な構造や性質を表す概 念として、1975年B. Mandelbrot ${ }^{1}{ }^{2}$ とって提唱されたもので、これ まで樹形や海岸線、脳波などを用いて多くの研究がなされている。 中でも、フラクタル次元*1を用いた分析手法は、一見不規則な事 象や形状の複雑さを定量的な指標として示すことが可能であり、そ の指標と人間の意識との関係性を明らかにできれば、都市・地域計 画の分野においても新たなる進展をもたらすものと考えられる。

これまでのフラクタル理論を用いた研究は、幾何学的考察に基づ くため、写真・地図などの 2 次元による分析が主体となっている。 しかし本来、自然界に潜在する複雑な構造の解明を目的とするなら ば、3 次元による空間的考察を行わなければ、実行力のある成果は 得られないと考えられる。建築学におけるフラクタル理論を用いた 既往研究としては、奥 ${ }^{2)}$ や佐藤・有馬 ${ }^{3)}$ の研究がある。前者は、 雑誌・書籍から収集した都市景観のスカイラインにおける輪郭線分 の統計量とフラクタル次元を用いた研究を行っている。後者らは、 都市中心地区、郊外、農山村部を対象に収集したスライドを用い、 コンピューター画像処理によるデータをもとにフラクタル次元によ る景観の定量化を行い、その解析手法の有用性について考察してい る。本稿は、これらに関連するものであるが、特に地域空間におけ る3次元空間情報を包含した陰影画像のフラクタル性のもつ構造的
意味を明らかにすることを目的としている。

筆者らの既往研究では、沿岸漁村地域を対象に、分析手法として、 3 次元陰影画像を用いた可視化モデルの構築4）を行い、フラクタ

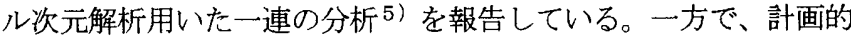
方法論として、アンケート調査より得られた認知領域と、3 次元陰 影画像を用いた可視領域の分析・考察を行い6)、さらにフラクタ ル性 $^{7)}$ との関倸性についても報告している。これらの成果を踏ま え、本稿では特に具体的な分析手法として、フラクタル次元解析の 整理・検証を行うことにより、3 次元陰影画像を用いた景観認知に よる可視化モデルの複雑性について、定量的な指標として提示する。

\section{3 次元陰影画像による可視領域}

\section{1 可視化モデル}

筆者らは既往研究 ${ }^{4}$ )において、伊豆・房総半島における59集落（表 1) を対象とし、「DEM(Degital Elevation Model:数值標高モデ ル)によるG I Sデータを用いた $3 \mathrm{D}$ 地形モデル」と「人間の視覚的 認知に近似できる逆二乗减衰を適用した光の広がり」をもとに景観 認知による可視化モデルの構築を行っている。具体的には、地域住 民の認知している「にぎわいの領域」を中心とし、点光源の高さ（1.6 $\mathrm{m})$ 、光の減衰始点 $(750 \mathrm{~m})$ 、光の減衰終点 $(1800 \mathrm{~m})$ 、モデル サイズ $(3600 \times 3600)$ といった設定条件のもと、図 1 に示す可視化 モデルを作成している。

\subsection{2 值画像の作成}

\section{[2 值化処理]}

ボックスカウンティング法*2によりフラクタル次元を測定する

\footnotetext{
*1 侏榎本建築設計事務所 修士(工学)

[元日本大学大学院〕

(宁275-8575 千葉県習志野市泉町 1-2-1)

*2 日本大学生産工学部建築工学科 研究員 $\cdot$ 博士 (工学)

*3 日本大学生産工学部建築工学科 教授・工博
}

*1 ENOMOTO \& Associates, M. Eng.

*2 Research Fellow, Dept. of Architecture College Industrial Technology, Nihon Univ., Dr. Eng.

*3 Prof., Dept. of Architecture College Industrial Technology, Nihon Univ., Dr. Eng. 


\section{表1 分析対象地域}

\begin{tabular}{|c|c|c|c|c|c|c|c|c|c|c|}
\hline & \multicolumn{5}{|c|}{ 房総半酋 (29地域) } & \multicolumn{5}{|c|}{ 伊豆半密 (30地域) } \\
\hline \multirow{8}{*}{$\begin{array}{l}\text { 分析 } \\
\text { 対 } \\
\text { 象 }\end{array}$} & 銧子 & 豊浜 & 17 & 白子 & 25 金谷 & 30 熟海 & 38 稲取 & 46 & 妻良 & 54 于于! \\
\hline & 外川 & 川津 & 18 & 中央 & 萩生 & 網代 & 坂户 & & 西子浦 & 55 八木 \\
\hline & 飯岡 & 大沢 & 19 & 富崎 & 竹岡 & 32 宇佐美 & 須崎 & 48 & 害見 & 56 土肥 \\
\hline & 片貝 & 䲧川 & 20 & 船形 & 佐䨘 & 33 伊東 & 下田 & 49 & 石部 & 57 \\
\hline & 太東 & 13 浜波太 & 21 & 富浦 & 大育 & 34 富户 & 田牛 & 50 & 岩地 & 内浦 \\
\hline & 大原 & 14 天面 & 22 & 高崎 & & 35 八橎野 & 下流 & 51 & 松崎 & 59 静浦 \\
\hline & 7 岩和田 & 15 太夫崎 & 23 & 勝山 & & 北川 & 44 石廊崎 & & 田子 & \\
\hline & 8 御宿 & 16 江見 & 24 & 保田 & & 37 片瀬 & 中木 & & 良里 & \\
\hline
\end{tabular}

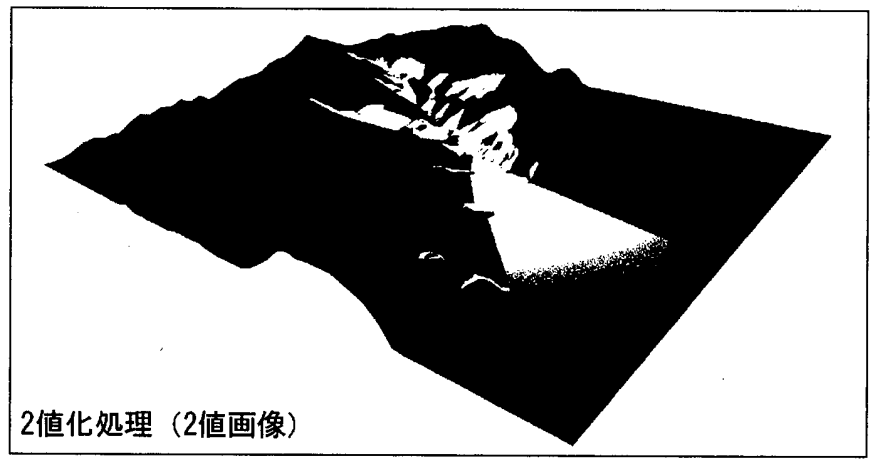

図 1 可視化モデル(例：石部集落)

ため、グレースケール陰影画像を 2 值化処理し、濃度が 0 または 1 の 2 值画像(モノクロ画像)を作成する。

\section{[しきい值の検討]}

2 值化処理のしきい值を決定するため、起伏の無いモデルを作成 し、既往研究 4$)$ と同様に光源を設定してグレースタール陰影画像 を作成する。

1〜16のしきい值で 2 值化処理し、白と黒の両方のピクセルを含 む輪状の部分の幅 $(\mathrm{W})$ を測定する。この輪状の部分は、8bitグレ一 スケールで表現し切れなかった部分であると共に、ボックスカウン ティング法でのフラクタル次元解析に大きな影響を与えるため、図 2 に示すよりに、この幅が狭くなり、なおかつ白の範囲が狭くなり 過ぎない 6 をしきい值とする。

以上の手順により得られた、3次元陰影画像であるグレースター 儿画像と 2 值画像を図 3 に示す。
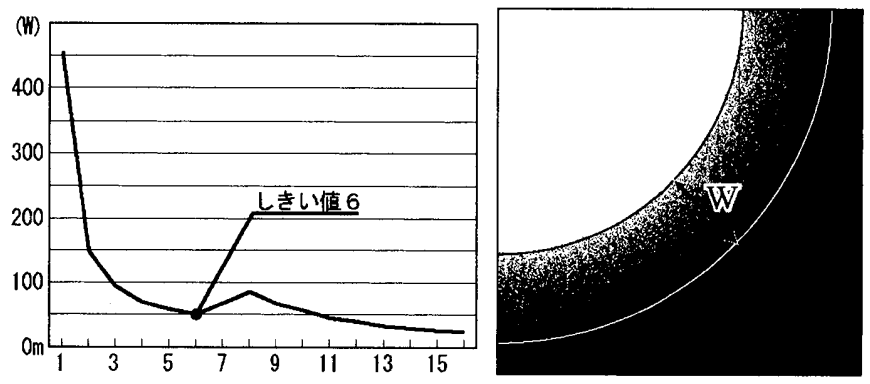

図 2 しきい值の検討
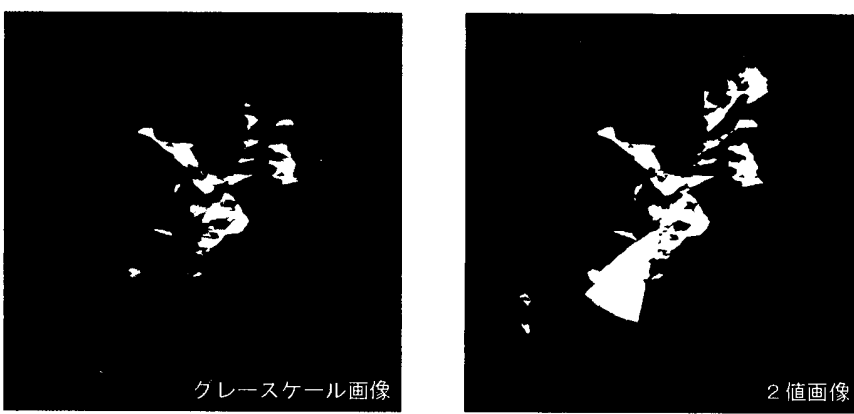

図 33 次元陰影画像(例：石部集落)

\section{3. フラクタル次元}

\section{1 ボックスカウンティング法}

数学の分野において、次元の定義は数多く存在する。その代表的 なものとして、相似次元、測定次元、被覆次元、容量次元などが挙 げられる。これらは全てB.Mandelbrotによるフラクタル次元と関 係がある。被覆次元は相似次元と測定次元の関係により求められ、 容量次元は測定次元と被覆次元を拡張させた考え方である ${ }^{8)}$ 。相 似次元、測定次元、被覆次元は、明確な繰り返しによる相似形状に 対して有効であり、海岸線などの実際の自然界に存在する不規則な 形状に対しては、容量次元が有効である。

本稿で用いるボックスカウンティング法によるフラクタル次元解 析は、解析対象画像の複雑性を容量次元として算出するものである。 具体的には、フラクタル次元解析は 2 值画像に含まれる白色Pixel の数をカウントすることで行われ、1〜2のフラクタル次元を示し、 值が大きいほど、一般に複雑性が高いとされる。

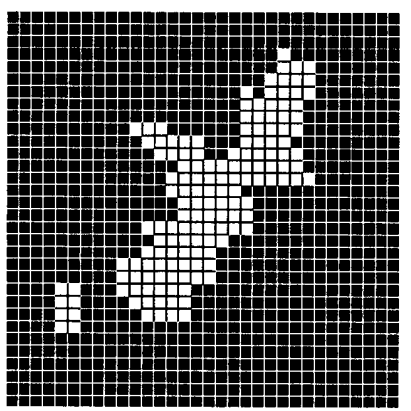

$32 \mathrm{Pixe}|\times 32 \mathrm{Pixe}|$

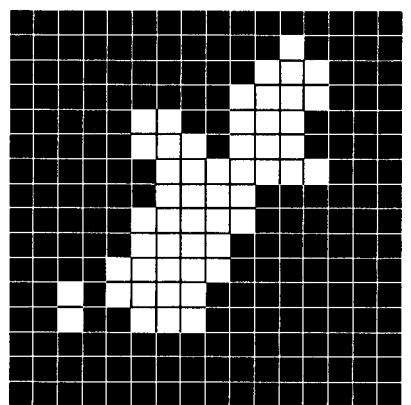

$16 \mathrm{P} i \mathrm{xe} \mid \times 16 \mathrm{Pixe}$
図 4 ボックスカウンティング法 (例: 石部集落)

2 值画像を一辺 $\mathrm{r}$ 画素の正方形で被覆する時(図 4)、対象とする 画素数を含む正方形の個数を画素間隔 $\mathrm{r}$ ごとに $\mathrm{N}(\mathrm{r})$ とすると、以 下のような式が成り立つ9)。

$N(r) \cdot r^{D}=C \cdot \cdots \cdot \cdot \cdot(1)$

ここで、Cは定数であり、この時のDがフラクタル次元となる。ま た、式(1)を変形すると

$\log N(r)=\log C-D \log r \cdots \cdot(2)$

となる。フラクタル次元Dは、 $\log \mathrm{r}$ と $\log \mathrm{N}(\mathrm{r})$ の直線の傾きであ り、最小二乗法により推定することができる。また、得られた回帰 直線が良好な直線性(決定係数 $\mathrm{R}^{2}$ が高い)を示す時に解析対象画像 のフラクタル性をもつことが確認することができる。

\section{2 フラクタル次元解析結果}

分析対象の59集落について、フラクタル次元解析を行った結果、 1. 5072〜1.8097のフラクタル次元Dと、0.9996〜0. 9939の決定係数 $\mathrm{R}^{2}$ が得られた。以下に、石部集落を例として得られたフラクタル 次元解析の結果を説明する。

ボックスカウンティング法を用いる際、陰影画像の白い部分(可 視領域)をカウントした。表 2 に示すように、陰影画像を被覆する ボックスサイズ $\mathrm{r}$ の初期值を $3600 \mathrm{~m} / 1024 \mathrm{Pixel}$ (約 $3.5 \mathrm{~m}$ ) とし、2の 乗数倍ずつ増加させた時の $\log \mathrm{r} 、 \log \mathrm{N}(\mathrm{r})$ を求めた。

ボックスカウンティング法を用いる際、陰影画像の白い部分(可 
ボックスカウンティング法における $\log r, \log N(r)$ の推移

\begin{tabular}{|c|c|c|c|c|}
\hline - & ボックスサイス & 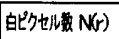 & $\log r$ & $\log N(r)$ \\
\hline 1024 & $3.5 \mathrm{~m}$ & 66402 & 0.55 & 4.82 \\
\hline 512 & $7.0 \mathrm{~m}$ & 17548 & 0.85 & 4.24 \\
\hline 256 & $14.1 \mathrm{~m}$ & 4820 & 1.15 & 3.68 \\
\hline 128 & $28.1 \mathrm{~m}$ & 1399 & 1.45 & 3.15 \\
\hline 64 & $56.3 \mathrm{~m}$ & 441 & 1.75 & 2.64 \\
\hline 32 & $112.5 \mathrm{~m}$ & 150 & 2.05 & 2.18 \\
\hline 16 & $225.0 \mathrm{~m}$ & 53 & 2.35 & 1.72 \\
\hline 8 & $450.0 \mathrm{~m}$ & 22 & 2.65 & 1.34 \\
\hline 4 & $900.0 \mathrm{~m}$ & 10 & 2.95 & 1.00 \\
\hline
\end{tabular}

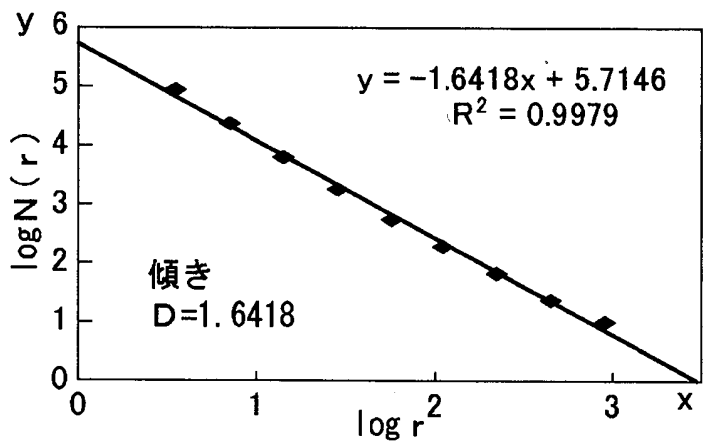

図 5 フラクタル次元Dの直線近似 (例: 石部地域)

視領域)をカウントした。表 2 に示すように、陰影画像を被覆する ボックスサイズ $\mathrm{r}$ の初期值を $3600 \mathrm{~m} / 1024 \mathrm{Pixel}$ (約 $3.5 \mathrm{~m}$ ) とし、2の 乗数倍ずつ増加させた時の $\log \mathrm{r} 、 \log \mathrm{N}(\mathrm{r})$ を求めた。

図 5 は、 $\log \mathrm{r} 、 \log N(\mathrm{r})$ の推移を回帰分析によって求めたもの である。一辺のピクセル数が1024〜16Pixelにおいて自己相似的な 構造のフラクタル次元の連続性を保ち、16Pixelを境に連続性を失 っている。この時、一辺のピクセル数が1024〜16Pixe1の範囲にお いてフラクタル次元Dである直線の傾きが-1.6418を示し、決定係 数は0.9979と高い值を示した。

\section{4. フラクタル次元の連続性による考察}

\section{1 各ボックスサイズ間の分析}

本報ではフラクタル次元の傾向を考察するため、以下の考えに基 づき、クラスター分析を用い分類する。ボックスカウンティング法 によるフラクタル次元解析で各ボックスサイズ間のフラクタル次元 を測定し、その変化を分析する。図 6 は59地域のフラクタル次元の

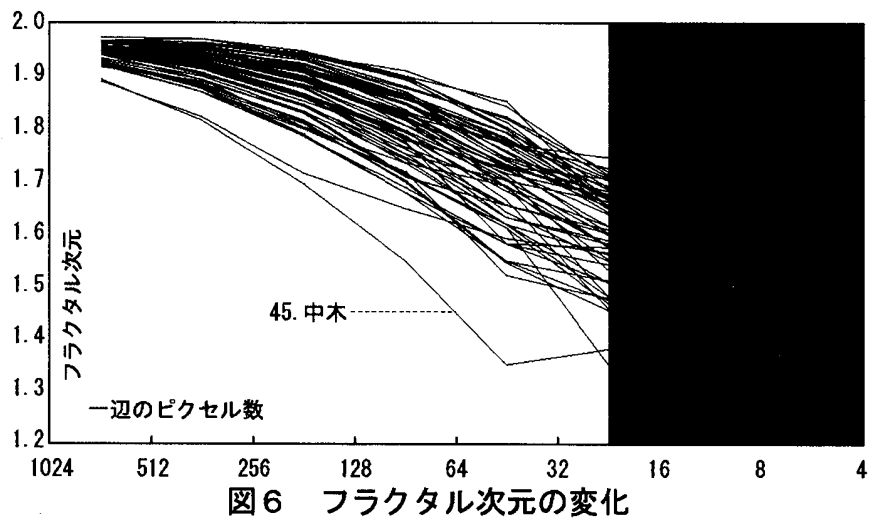

変化を示している。一般的な傾向として、一辺のピクセル数が16〜 4pixe1の区間においてフラクタル次元は連続性を失っていることが わかる。よってクラスター分析を行うにあたり、1024〜16pixelの 区間でのフラクタル次元を用いる(図6に示すように、中木は他の 集落と変化の様相が著しく異なるため分析より除外する)。

\section{2 フラクタル次元の連続性による地域の分類とその傾向}

フラクタル次元の変化量 (図 7 )を求め、多次元データとし、地域 間のユークリッド距離をもとにクラスター分析(ウォード法*3)を行 った(樹形図を図 8 に示す)。その結果、フラクタル次元の連続性 として 4つの傾向を読み取ることができた。各 T Y P Eごとのフラ クタル次元の推移を図9に示し、その特徵を以下に整理する。図 9 の下図は各 TY P Eごとの 3 次元陰影画像の例であり、可視領域の 広がりが不規則な形状の複雑さをもつことがわかる。

[T Y P E(1)]ボックスサイズが大きくなるにつれ、フラクタル次 元の減少する幅が大きくなる特徴を持つ地域である。

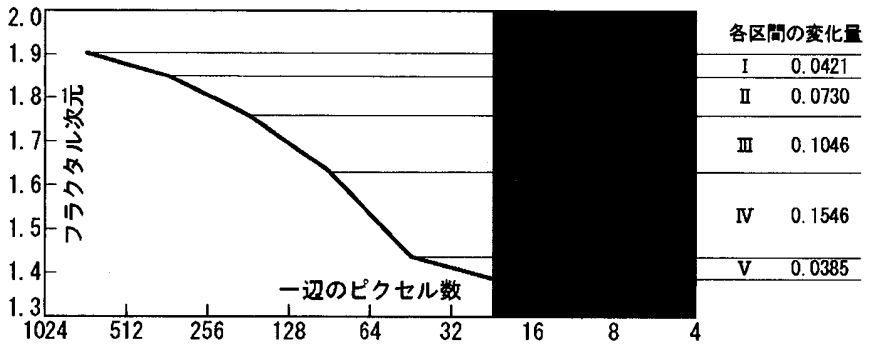

図 7 フラクタル次元の変化量 (例: 石部地域)

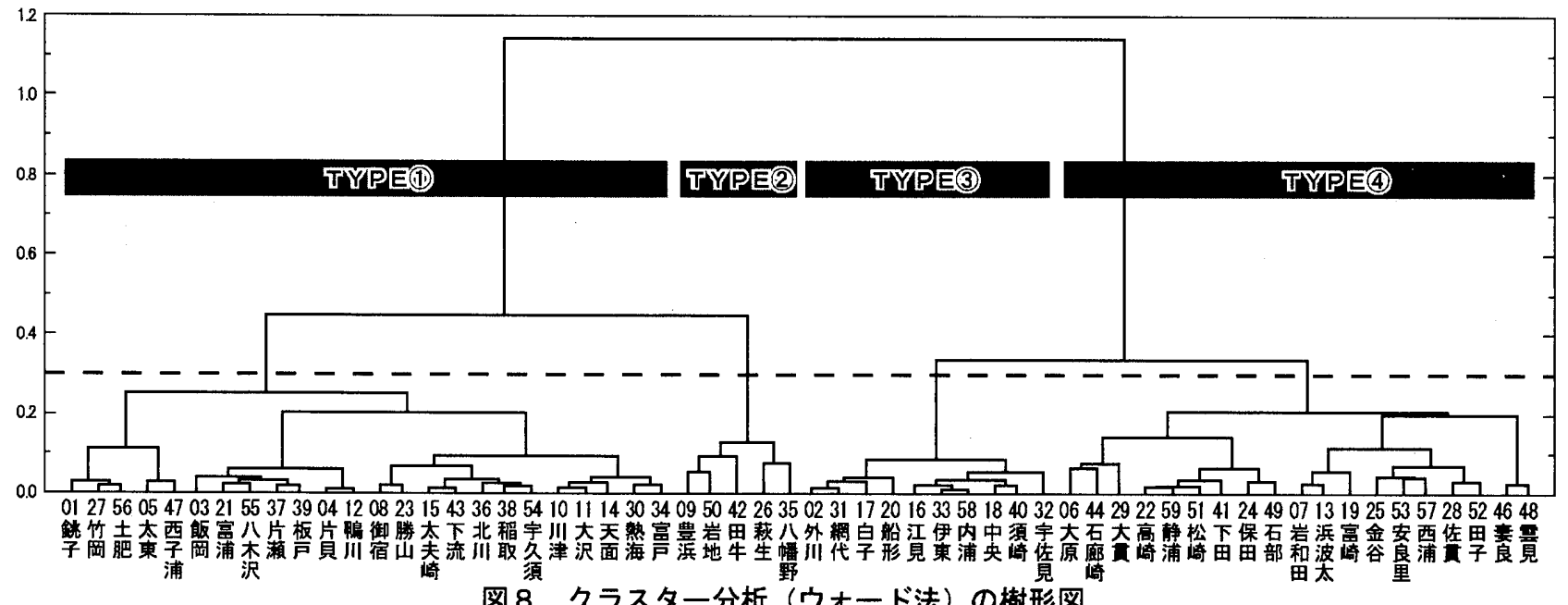

図 8 クラスター分析 (ウォード法) の樹形図 

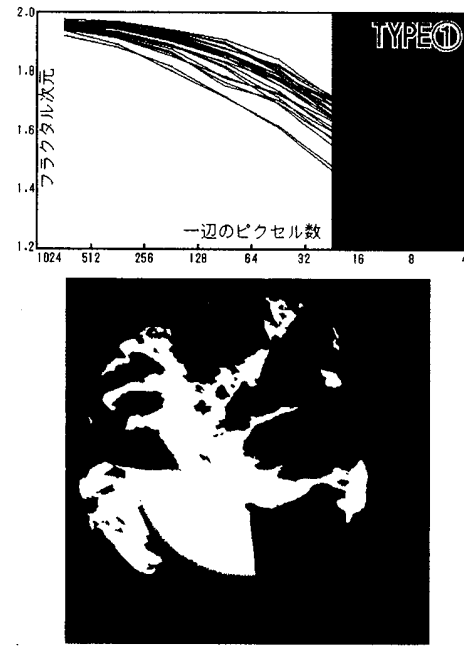

TYPE(1)（例 : 54. 宇久須）
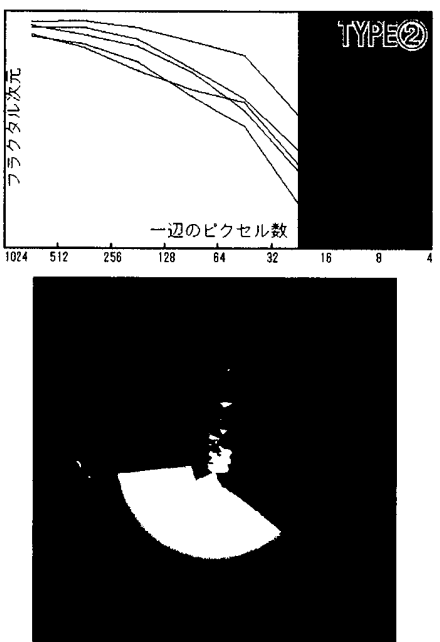

TYPE(2)（例 : 9. 豊浜)
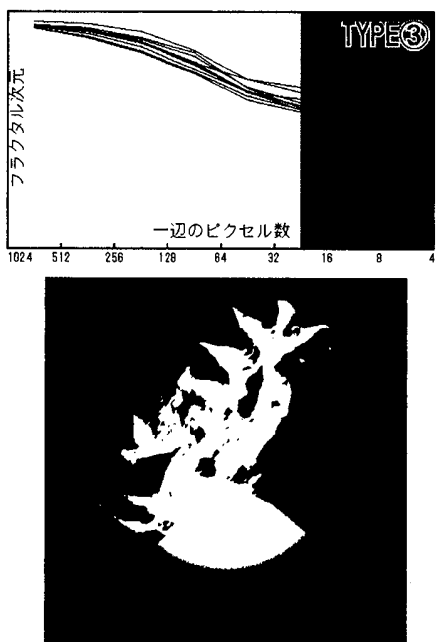

TYPE(3)（例 : 31. 網代)
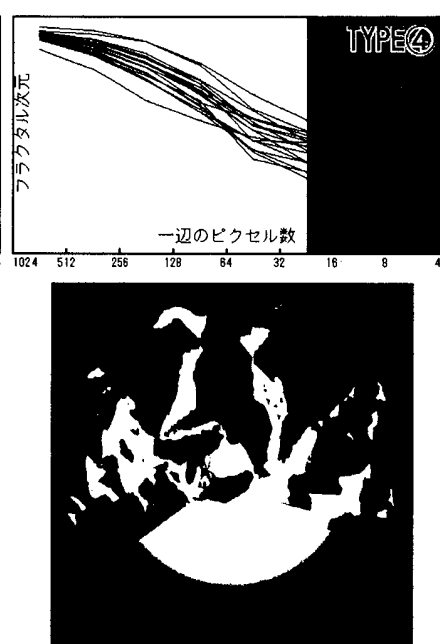

TYPE(4)（例：24. 保田）

図 9 TYPE別のフラクタル次元の推移

[TYPE(2)]一辺のピクセル数が64〜16pixelの区間でフラクタ ル次元が急に減少している特徴を持つ地域である。

[TYPE(3)]ボックスサイズが大きくなるにつれ、フラクタル次 元が一定の幅で減少し、比較的に高いフラクタル次元の特徴を持つ 地域である。

[T Y P E(4)]一辺のピクセル数が128〜32Pixe1の区間でフラクタ ル次元が急に減少しているが、64〜16Pixe1の区間では减少の幅が 少なくなっている地域である。

\section{5. まとめ}

以上のことより、複雑な地形をもつ沿岸漁村地域を対象とし、(1) 3 次元陰影画像を用いた景観認知による可視化モデルのフラクタル 性の存在を明示し、(2)海・まち・山を複合（一体）的にとらえた一 見不規則に見える可視領域の広がりを定量化することができた。ま た(3)ボックスカウンティング法によるフラクタル次元の連続性の限 度（スケール）を具体的な数值（16４pixel）として把握すること もでき、(4)一定のスケール変化（1024〜16pixelの区間）によるフ ラクタル次元の連続性の様相により、分析対象とした集落を $4 つ の$ TYPEに分類し、そのTYPEごとの特徴を把握することがきた。

ボックスカウンティング法におけるフラクタル次元解析では、全 体のフラクタル次元だけでなく、ボックスサイズを大きくする過程 でのフラクタル次元の連続性の様相により、分類された集落のまと まりは、類似の空間構造（空間のスケール変化）をもっていると考 えられる。

フラクタル理論は、アインシュタインの相対性理論と並ぶ、20世 紀で最も重要な科学理論であろうと言われている。その後多くの分 野で研究が進められているが、未だ発達段階である。本稿において 得られた地域住民の視点に立脚した可視領域の広がりのフラクタル 次元と地域空間を形成している住民の意識との相互の関係性が明ら かにできれば、今後の都市・地域計画の分野における新たなる可能 性を持つ有効な手法論に成り得ると考えられる。筆者らは既往研究 10）11において、環境を認知するということに対し、圏域的な面か らアプローチすることにより、周辺環境と地域空間との関係性から 住民の持つイメージ構造を明らかにしてきた。今後の展開として、
定量化されたフラクタル次元と地域住民に対する環境認知の調査 より得られた「認知領域の広がり」や「空間構造の多義性 ${ }^{12)} \cdot$ わ かりやすさ13)」などとの相互の関倸性を分析することにより、フ ラクタル次元のもつ構造的意味を考察していく予定である。

注記

*1 フラクタル次元は、自己相似性を定量化した数值であり、相似性をもとにし た测度で、位相次元と異なり、非整数值をとることが特徴である。

*2 ボックスカウンティング法は容量次元としてフラクタル次元を算出する方法 である。容量次元の他に代表的なものとして、相似次元、测定次元、被覆 次元などがある。

*3 クラスター分析 本稿では、広く応用されている最近隣法、最遠隣法、重心 法、ヴォード法などを試みた結果、最も分かり易く分類されたヴォード法 を適用した。

参考文献

1) Benoit B.Mandelbrot : The fractal geometry of nature、W.H. Freemanand Company、1977、広中平祐監訳 : フラクタル幾何学、日経サイエンス社、1985

2）奥俊信：都市スカイラインの視覚形態的な複䧴さについて、日本建築学会計 画系論文報告集、第412号、PP. 61 71、1990.6

3）佐藤誠治, 有馬隆文 : 都市景矮画像の形態特性に関する研究ーコンピュータ 画像処理を用いた都市景锥研究一、日本都市計画学会都市計画論文集、No. 27、 PP. 739 744、1992. 11

4）根來宏典，柏原創、蝶名林秀明，山田悟史，大内宏友：3次元陰影画像を用いた 景㓋認知による可視化モデルの構筑、日本建築学会技術報告集、第20号、 PP. 359 362、2004. 12

5）根來宏典，蝶名林秀明，大内宏友：3次元陰影画像を用いた可視領域のフラク タル性について一沿岸漁村地域における被境認知の空間構造に関する研究一、 第27回情報・システム・利用・技術シンポジウム (報告)、PP. 265〜268、 2004. 12

6）根來宏典, 大内宏友 : 地域住民の景㓋認知における可視領域とその構成につ Wて、日本建筑学会総合論文誌、PP. 102 107、2005. 2

7）蝶名林秀明, 根來宏典, 大内宏友：地域住民の可視領域のフラクタル性と環境 認知との関保性についてー沿岸漁村地域における3次元陰影画像を用いた 分析・考察一、日本建築学会2004年度関東支部研究発表会、2005.3

8) Carl Bovil : FRACTAL GEOMETRY in Architecture and Design Birkhauser Boston、1996、三井直樹他共訳 : 建築とデザインのフラクタル 幾何学、鹿島出版会、1997

9）高安秀樹 : フラクタル、朝倉書店、pp. 196、1986

10）根來宏典, 大内宏友：噮境認知による沿岸漁村地域にお讨る複合圈域の形成 プロセスー地域住民における㻴境認知にもとづく計画圈域の設定その1一、 日本建筑学会計画系論文集、第573号、PP. 63 70、2003.11

11）根來宏典, 蝶名林秀明, 大内宏友 : 沿岸漁村地域のにお汀る複合圈域の変化の 要因とその内部構造について一地域住民における環境認知にもとづく計画 圈域の設定その 2 -、日本建筑学会計画系論文集、第587号、PP. 73 80、 2005.1

12) A.Rapoport \& E.Kantor : Complexity and Ambiguity in environmental design,AIP Journal, 1968.7

13) Kevin Lynch : The Image of the City, the Massachusetts Insitute of Technology、1960、丹下健三他共訳 : 都市のイメージ、岩波書店、1968

[2005年 4 月19日原稿受理 2005年 7 月22日採用決定］ 